\title{
Setback to and Encouragement of Feedback: Teacher and Student Perspectives
}

\author{
Felicitas Ogonna Ejinkonye and Romy O. Okoye
}

\section{ABSTRACT}

The research explored setback to, and encouragement of feedback as perceived by teachers and students. Three research questions guided the study. The population of the study constituted 180 teachers and 3200 students in government owned secondary schools in Ekwusigo L.G.A of Anambra State. Simple random sampling technique was used to draw the sample of teachers and students. Two questionnaires, one for teachers and one for students were used to collect data. Arithemetical mean was used in answering the research questions. The results revealed that all the stipulated factors constituted setbacks to teachers in giving feedback to their students. All the teachers indicated that all the listed items can encourage them in giving feedback to their students. Also, almost all the items except one constituted setback for the students in receiving feedback from their teachers. It was recommended that workload of teachers should be moderate, and the teacher should be relieved of other duties that may affect teaching and learning. Also, students' seriousness should be boosted by ensuring that they repeat class when they fail among others.

Keywords: Feedback, Students, Teachers, Teaching and Learning.

Published Online: July 15, 2021

ISSN: $2736-4534$

DOI : 10.24018/ejedu.2021.2.3.118

Felicitas Ogonna Ejinkonye

Department of Psychology, School of Education, Federal College of Education, Eha-Amufu, Enugu Staten. Nigeria.

(e-mail: iamfelicitas@gmail.com)

Romy O. Okoye

Department of Educational Foundations, Nnamdi Azikiwe University, Awka, Nigeria.

(e-mail: rookoye ${ }^{\circledR}$ gmail.com

ro.okoye@unizik.edu.ng)

*Corresponding Author

\section{INTRODUCTION}

In the teaching and learning process, the job of the teacher is to facilitate learning while that of the student is to acquire what is being taught. As teaching is going on, the students need to be given feedback on their performance. This enables them to know how they are coping with the task designed for them. Feedback according to De Franzo is the helpful information or criticism about prior action or behavior from an individual, communicated to another individual (or a group) who can use that information to adjust and improve current and future actions and behaviours [1]. Also, Hattie and Timperley, in Wisniewski explained feedback as information provided by an agent regarding aspect of one's performance or understanding. This implies that feedback reveals to the recipients the extent they have gain on the teaching content exposed [2] To Hattie, the goal of feedback is to provide students with insight that helps them to improve their performance. Also feedback according to Binu, provides new information specifically related to the task or process of learning that fills the gap between what is understood and what is aimed to be understood. It helps the student understand the subject better and gives them clear guidance on how to proceed with their learning [3].

Feedback in education help both students and teachers strengthen the learning process and can help students improve the chances of their success [4]. Giving feedback and correcting errors may serve not only to let learners know how well they have performed but also to increase motivation and build a supportive classroom climate [5]. Effective feedback is a tool for continuous learning; it can motivate and improve performance. It was noted that feedback is a very effective technique in assessment of learning and its absence during teaching rids classroom assessment of its effectiveness in enhancing learning [6].

Questioning, giving assignments, class works, projects, tests etc., are ways the teacher obtains information for feedback. The most commonly used among these are tests and assignments. Students on the other hand, obtain their own feedback from the teacher through praise, commendation, scores and corrections in tests and assignments etc. Research by Hattie, as cited in Hattie and Timperley reported that some types of feedback are more powerful than others [6]. The study showed that receiving feedback on tasks had higher effect sizes than feedback in form of praise, rewards and punishment. Rasario et al study on the effect of teachers' homework follow-up practices on students EFL performance revealed that three homework follow-up practices (checking homework orally, checking homework on the board and collecting and grading homework) had a positive impact on students' performance [7].

There are series of anticipated factors that can influence giving and receiving of feedback. They include truancy, peer group influence, motivation of teachers through promotions, knowledge of subject matter, time factor, etc. Fareo, in his study on influence of truancy on academic achievements of secondary school students found that truancy negatively affect education achievement of secondary school students in Maiha Local Government Area. They also found that there was a significant relationship between truancy and academic 
performance of students. Truancy therefore has serious effect on student learning and their general academic performance [8]. Idris on the other hand found out that peer group have a significant influence in the academic performance of adolescent students [9]. Again, Karachiwala research on promotion incentive in public sector evidenced from Chinese schools showed that promotion incentive influences the effort of public employees [10].

Some reviewed work like Rachelle, Trine and Odd in their study on what counts as quality feedback assumed that the perceived quality of feedback is related to the specific teaching-learning environment. They explored what students and teachers perceived to be quality feedback in their courses and how these perceptions are related to those of their own teaching-learning environments. The subjects where students and teachers from three different courses that vary in their disciplines and pedagogical approaches. The data was analyzed using thematic analysis. Interview was the instrument used. The finding showed that the criteria for what counts as quality feedback vary across course contexts and between students and teachers. The differences are related to the importance attributed to certain structural, epistemic, and relational-affective characteristics of the course environment. It was recommended that more context-sensitive ways of evaluating and developing the quality of feedback in higher education should be developed. [11] Omar, Safa, Al-Talib and Abeer did a study on factors affecting some students' response to feedback. They tried to discover factors that affect some students' response to their teachers' feedback on writing at the faculty of education in Nalut. Both qualitative and quantitative methods were used for collecting data. Questionnaire, interview, and student compositions were used to collect data. Two teachers and 20 students from both fourth and third year students of English language participated in the study. Only third year students wrote composition and were interviewed. The result revealed that students were careless towards teachers' feedback. Most of them did not respond even to spelling mistakes and are not interested in both grades and feedbacks. Moreover, the time and teachers' way of assessing the quality of their written work affected their revision [12].

Harrison, Konings, Cees and Vander [13] did a study on factors which aid or hinder receptivity to feedback. A constructivist grounded theory approach was used to conduct six focused group in three medical schools, in three separate countries, with different institutional approaches to assessment. Data was analyzed iteratively. The finding showed that receptivity to feedback was enhanced by assessment culture which promoted students' agency, by the provision of authentic and relevant assessment, and by appropriately scaffolding to aid the interpretation of feedback. Provision of grades and comparative ranking was found to provide a helpful external reference but appeared to hinder the promotion of excellence [13]. Chaqmaqchee also investigated the academic staff method of feedback and the use of traditional pedagogy (teacher written feedback) or the novel mode (online and peer feedback) at Salahaddin University in Erbil. Qualitative and quantitative method of data collection was used. The finding showed that some instructors use peer and online feedback approach which help students to be reflective and critical thinkers while most of them resort to teacher written feedback [14].

In Nigerian secondary schools, observations show that corrections to tests and assignments are sometimes not done. This is evidenced from the students' exercise books. The use of class work and homework to guide students' performance is lacking [15] The W.A.E.C Economics Chief Examiner's report of 2015, identified poor feedback as a possible cause of poor performance, hence it suggested as a way to improve performance the helping of students to identify and correct their mistakes [16]. Considering the importance of effective feedback, it is therefore pertinent to look at factors that hinder or encourage giving of feedback to students. The reviewed studies explored perception of students on what constitutes quality feedback, different approaches used to provide feedback (Rachelle,Trine \& Odd[11], Chaqmaqchee [14]). Also, studies conducted on feedback tends to focus on effect of feedback and preferences on different types of feedback (Wisniewski, Zierer \& Hattie [2] and Mulliner \&Tucker [17]). Most of the studies are not done in Nigeria and none was found on hindrances to feedback hence this study aimed to fill the gap by trying to identify setbacks to and encouragement of feedback with a view to providing recommendations that would help to enhance improved effective feedback for better learning and student performance.

Specifically, the work studied:

- Factors that constitute setbacks to teachers in giving appropriate feedback/corrections to students.

- Those factors that encourage teachers in giving feedback/corrections to their students.

- Factors that constitute setbacks to students in receiving feedback given by the teachers.

The research questions to guide the study are:

1. What factors constitute setbacks to teachers giving appropriate feedback/corrections to students?

2. What are those factors that encourage teachers in giving feedback/corrections to their students?

3. What factors constitute setbacks to students' in receiving feedback given by teachers?

\section{METHOD}

This work used descriptive survey research design. The research was carried out in Ekwusigo L.G.A. of Anambra State. Teachers and students in government- owned secondary schools in the local government constituted the population of the study. The local government area had eight schools with 180 teachers and 3, 200 students. Using simple random sampling technique, a sample of 10 teachers and 20 SS1 students from each school was drawn. This resulted in a sample of 80 teachers and 160 students.

Through review of literature and interview, two questionnaires, one for teachers and one for students were developed namely: Teachers' Feedback Questionnaire and Students' Feedback Questionnaire.

Each item in the two instruments had 5-point Likert response scale, ranging from strongly agree to strongly disagree. The Teachers' Feedback Questionnaire had two sections. Section A was on factors that constituted setback to teachers in giving appropriate feedback/correction to students while Section B was on those factors that encourage the 
teacher in giving feedback/corrections to the students. The questionnaire for the students contained factors that hinder the students from improving after receiving feedback. The reliability of each instrument was ascertained using Cronbach Alpha method. Reliability coefficients of 0.8 and 0.8 were gotten for Sections A and B respectively of teachers' instrument while 0.7 reliability co-efficient was gotten for the students' questionnaire.

Direct delivery technique was employed in administering the instruments to ensure reduced losses. The data collected were analyzed using arithmetic mean. The items had 5 response options: strongly agree to strongly disagree, weighted from 5 to 1 , respectively. The mean score of the scale is 3.00. Therefore, mean score of 3.00 and above implied agreement with the statement in the item while mean score below 3.00 implied disagreement.

\section{RESUlT}

A. What Factors Constitute Setback to Teachers in Giving Appropriate Feedback/Corrections to Students?

TABLE I: MEAN RESPONSES BY TEACHERS' ON FACTORS THAT CONSTITUTE SETBACK TO GIVING FEEDBACK

\begin{tabular}{|c|c|c|c|c|}
\hline & Items & Number & Mean & Remark \\
\hline \multirow{2}{*}{$\begin{array}{l}1 . \\
2 .\end{array}$} & Limited time to teach & 80 & 3.9 & Agree \\
\hline & $\begin{array}{l}\text { So much content to cover in } \\
\text { curriculum }\end{array}$ & 80 & 3.6 & Agree \\
\hline \multirow{2}{*}{$\begin{array}{l}3 . \\
4 .\end{array}$} & Truancy by the students & 80 & 4.0 & Agree \\
\hline & $\begin{array}{l}\text { Expectation by quality } \\
\text { assurance policy that a } \\
\text { Teacher should give a } \\
\text { required number of } \\
\text { assessment }\end{array}$ & 80 & 3.2 & Agree \\
\hline 5. & $\begin{array}{l}\text { Teachers not preparing well } \\
\text { for lessons }\end{array}$ & 80 & 3.8 & Agree \\
\hline 6. & $\begin{array}{l}\text { Lack of knowledge of the } \\
\text { subject matter by teachers }\end{array}$ & 80 & 3.6 & Agree \\
\hline 7. & $\begin{array}{l}\text { Too much workload by the } \\
\text { teacher }\end{array}$ & 80 & 4.2 & Agree \\
\hline 8. & $\begin{array}{l}\text { Students showing } \\
\text { unseriousness }\end{array}$ & 80 & 3.9 & Agree \\
\hline 9. & Time of lesson & 80 & 3.3 & Agree \\
\hline 10. & $\begin{array}{l}\text { Unqualified teacher teaching } \\
\text { the subject }\end{array}$ & 80 & 3.8 & Agree \\
\hline 11. & $\begin{array}{l}\text { Lack of love for students by } \\
\text { teachers }\end{array}$ & 80 & 3.3 & Agree \\
\hline 12. & $\begin{array}{l}\text { Laziness on the part of the } \\
\text { teacher }\end{array}$ & 80 & 3.8 & Agree \\
\hline 13. & $\begin{array}{l}\text { Students not reflecting the } \\
\text { corrections done by the } \\
\text { teacher in their exercise book }\end{array}$ & 80 & 4.5 & Agree \\
\hline 14. & $\begin{array}{l}\text { Teachers' engagement in } \\
\text { other things apart from } \\
\text { teaching }\end{array}$ & 80 & 3.7 & Agree \\
\hline 15. & $\begin{array}{l}\text { Teachers not being motivated } \\
\text { to giving feedback because } \\
\text { students do not fail or repeat } \\
\text { class. }\end{array}$ & 80 & 4.3 & Agree \\
\hline
\end{tabular}

From the result in Table I, all the items have mean ratings up to 3.00 showing that the teachers agreed that they constitute setbacks for them in giving feedback to their students. It could be observed that the factor that was rated highest was, students not reflecting the corrections done by the teacher in their exercise books $(X=4.5)$. This was followed by teachers not being motivated to give feedback because students do not fail or repeat classes $(X=4.3)$; teachers having too much workload $(X=4.2)$; and then truancy by the students $(X=4.0)$.
B. What are Those Factors that Encourage Teachers in Giving Feedback/Corrections to Their Students?

TABLE II: MEAN RESPONSES ON FACTORS THAT ENCOURAGE TEACHERS TO GIVE FEEDBACK TO STUDENTS

\begin{tabular}{clccc}
\hline S/N & \multicolumn{1}{c}{ Items } & Number & Mean & Remark \\
\hline 1. & $\begin{array}{l}\text { Having enough time for } \\
\text { teaching }\end{array}$ & 80 & 4.4 & Agree \\
2. $\quad \begin{array}{l}\text { Having less content to } \\
\text { cover in the curriculum } \\
\text { Giving promotion and } \\
\text { other benefits to } \\
\text { teachers }\end{array}$ & 80 & 3.9 & Agree \\
4. & $\begin{array}{l}\text { Expectation by quality } \\
\text { assurance policy that } \\
\text { teachers should give } \\
\text { correction to their } \\
\text { students' works }\end{array}$ & 80 & 4.6 & Agree \\
Teacher knowing the \\
subject they teach
\end{tabular}

From the result in Table II all the items have mean ratings up to 3.00 showing that teachers agree that these factors encourage them in giving feedback to their students. Though all the items were considered factors, the ones that were considered the most important factors were: giving promotion and other benefits to teachers $(x=4.6)$, reduced workload $(X=4.6)$ and positive performance of students after feedback $(X=4.6)$. The other factors that followed were having enough time for teaching $(\mathrm{X}=4.4)$, students displaying interest in learning $(\mathrm{X}=4.3)$, and expectation by the quality assurance policy that teachers should give corrections to their students' work $(\mathrm{X}=4.2)$.

\section{What Factors Constitute Setback to Students in Receiving Feedback Given by Teachers}

TABLE III: MEAN RESPONSES ON SETBACK To RECEIVING FEEDBACK By

\begin{tabular}{|c|c|c|c|c|}
\hline $\mathrm{S} / \mathrm{n}$ & Items & Number & Mean & Remark \\
\hline 1. & Peer group influence & 160 & 4.4 & Agree \\
\hline 2. & $\begin{array}{l}\text { Parents not checking } \\
\text { their children's works } \\
\text { at home }\end{array}$ & 160 & 4.3 & Agree \\
\hline 3. & $\begin{array}{l}\text { Limited time for } \\
\text { learning }\end{array}$ & 160 & 2.2 & Disagree \\
\hline 4. & $\begin{array}{l}\text { Too much content to } \\
\text { be studied by the } \\
\text { students }\end{array}$ & 160 & 3.6 & Agree \\
\hline 5 & Laziness of students & 160 & 4.1 & Agree \\
\hline 6. & $\begin{array}{l}\text { Lack of } \\
\text { supervision/follow up } \\
\text { by the teacher }\end{array}$ & 160 & 3.5 & Agree \\
\hline 7. & Truancy by students & 160 & 4.2 & Agree \\
\hline 8. & $\begin{array}{l}\text { Distraction } \\
\text { social media }\end{array}$ & 160 & 4.1 & Agree \\
\hline 9. & $\begin{array}{l}\text { Syndrome of moving } \\
\text { to the next class even } \\
\text { when students fail }\end{array}$ & 160 & 3.2 & Agree \\
\hline 10. & $\begin{array}{l}\text { Too many subjects } \\
\text { and activities }\end{array}$ & 160 & 3.3 & Agree \\
\hline 11. & $\begin{array}{l}\text { Students not knowing } \\
\text { the importance of } \\
\text { correction }\end{array}$ & 160 & 4.2 & Agree \\
\hline
\end{tabular}


Ten items have mean rating above 3.00 showing that students agreed that these factors were setbacks for them in receiving feedback given by the teacher. One item has mean rating below 3.00 showing that it is not a setback to the students in receiving the teachers' feedback. Of the items that were considered factors, the two that came top-most were peer group influence $(X=4.4)$ and parents not checking their children's work at home $(X=4.3)$. The other two that followed are truancy by students $(X=4.2)$, and students not knowing the importance of correction $(X=4.2)$.

\section{DISCUSSION OF RESULT}

\section{A. Teacher Setback to Giving Feedback}

The result showed that all the items were considered factors. This notwithstanding, the teachers identified 'students' not reflecting correction done by the teacher in their exercise books' as the most contributing factor. This should not be surprising because failure of students to reflect teachers' corrections in their books should be demoralizing to the teachers thereby not encouraging them to make such corrections in future. The next factor in order of importance is the issue of teachers not being motivated to give feedback because students do not fail or repeat a class. The essence of giving feedback while teaching is to enhance learning, which increases the chances of students passing during promotion examinations. When there is a policy that students are promoted to the next class, whether or not they pass, the teacher lacks the motivation to give feedback with a view to enhancing learning. Too much workload by the teachers also came top among the factors that deter the teachers from giving appropriate feedback to students. It is obvious that when a teacher has too much workload, she may be struggling to cover the required workload thereby having less time for corrections to students work. This definitely will affect the students' performance. The above is affirmed by Rose and Sika who's finding revealed that influence of teacher's workload on academic performance was significant and also that for every one unit increase teacher work load, there was a decrease in pupils achievement.[18]. Similarly, Chirimi found that increased teacher workload result in poor academic performance among students in secondary schools in Tanzania.[19]

\section{B. Things Encouraging Giving of Feedback by the Teacher}

The factor considered most encouraging was the giving of promotion and other benefits to the teacher. There is no doubt that giving of promotion and other benefits to the teacher will help to motivate them to devote more time to their work which will result in giving feedback to students. This result agrees with that of Karachiwalla who found that promotion incentives influence the effort of public employee.[10]. Reduction of teachers' workload also came top-most as a factor. This has something in common with the next highly rated factor which is concerned with having enough time for teaching. Obviously, when teachers have reduced workload, they will have enough time for teaching, part of which is the provision of feedback. The next top-most encouraging factor was positive performance of students after feedback. There is no doubt that the teacher will be highly encouraged to keep giving feedback when they find out that the exercise result in positive performance by students.

Though all the items listed were considered as factors that encouraged giving of feedback, it was surprising that teacher's knowledge of the subject matter was given the least rating, despite the importance of this factor in teaching and learning, because no one gives what they do not have. The importance of this factor is supported by the result of Kiamba, Mutua and Mulwa who established that a teacher's subject matter knowledge had significant influence on students' achievement on Kiswahili language.[20]. Also, Ntibi, Neji and Agube study stressed the importance of knowledge of subject matter through their finding that there is significant influence of students' perception of teacher knowledge of subject matter and achievement in physics.[21]

\section{C. $\quad$ Factors that Constitute Setback to Students in Receiving Feedback given by Teachers}

From the result, the factor that constitute highest setback to receiving feedback by students was peer group influence. There is doubt that peer group influence can distract students such that they have divided attention to schoolwork, thereby not having time to affect the corrections given by the teacher. The effect of peer group on students was buttressed by Idris who found out that peer group has significant influence in the academic performance of adolescent students [9]. However, peer feedback had a positive effect on the acquisition of physical education skills which is contrary with the finding of this work [22].

Parent not checking their children's work at home also came top among the factors that constitute setback to receiving feedback by the students. This is not surprising since a check on the students work by parents will motivate them to be up to date in the school task expected of them. The next important factor that constitutes setback is truancy by students. Truancy sometimes keeps a student absent from school and class, and the concerned student may not be around when corrections are given by the teacher. Therefore, Fareo's finding that there was a significant relationship between truancy and academic performance of students supports the finding of this work which indicated that truancy deter the student from receiving feedback given by the teacher [8]. The students not knowing the importance of correction have the same rating with truancy as a factor. This is not strange since lack of knowledge can lead to neglect. No wonder Sivinick stated that bulk of problem of students' feedback is students' belief about feedback and their lack of understanding of the importance of feedback [23].

\section{RECOMMENDATIONS:}

Based on the findings of the study, it was recommended that:

1) Workload of teachers should be moderate, and the teachers should be relieved of other duties that may affect their focus in teaching and learning.

2) Curriculum content should be made moderate for each week and then time of lesson can be extended from 40minutes to 50minutes to accommodate giving of corrections.

3) Students should be educated on the importance of corrections to the attainment of their set educational 
objectives.

4) Remuneration should be improved such that teachers will be discouraged from engagement in other things apart from teaching. Also, they should be promoted as and when due,

5) Students' seriousness should be boosted by ensuring that they repeat class when they fail.

6) Truancy of students should be checked by proper keeping and monitoring of attendance registers and corroboration with parents.

\section{REFERENCES}

[1] S. E. De Franzo. "Five reasons why feedback is important". https://www.snapsurveys,com/blog/5-reason-feedbackimportant/.2015.

[2] B., Wisniewski, K., Zierer, \& J. Hattie. "The power of Feedback. Revisited: A meta-analysis of educational feedback research". Frontiers in psychology educational psychology. https://doi.org/10.3389/fpsyg/2019.03087. 2020.

[3] P. M., Binu. (2020). "The role of feedback in classroom instruction". www.research gate.net.

[4] J. Scarlett. (2016). Types of feedback. https://resources.eln.10/ty.

[5] K. T., Sichanga, J. H. C., Mfuni, H. J. Nenty, \& P., Chakolisa. (2014). Factors influencing quality of feedback in teaching in Botswana senior secondary school. International Journal of Research in Social Science, 4(1). https://ijsk.org/ijrss

[6] J. Hattie, \& H. Timperley, (2007). The power of feedback.https://www.journals.sagepub.com.

[7] P. Rosario, J. C., Nucez, G. Vallego, J. Cunha, T. Nunes, N. Suarez, S. Fuentes, T. Moreira, (2015). The effect of teachers' homework followup practices on students EFL performance: A randomized group design. https://doi.org/10.3389/psyg.2015.01528.

[8] D. O. Fareo. "Influence of truancy on academic achievements of secondary school students in Maiha Local Government Area of Adamawa State". East African Scholars Journal of Education, Humanities and Literature.2(8) pp.430-438. 2019.

[9] A. Idris, "The factors and effect of peer group influence on academic performance of adolescent students in Niger State”. 2019.

[10] N. Karachiwalla, \& A. Park. (2017). "Promotion incentives in public sector: Evidence from Chinese schools". IZA Institute of Labour Economics.www.iza.org.

[11] Rachelle, E.;Trine, F.\& Odd. R.S. (2020). "What counts as quality feedback"? Displinary difference in students' and teachers' perceptions of feedback. In book quality work for higher education. pp155174.Doi:10.1007/978-3-030-41757-49.

[12] H. Omar, K. Safa, Al-Talib; I. Abeer. "Factors affecting some students responses to feedback on writing". www.researchgate.net. 2020.
[13] C.J. Harrison, K.D. Konings, P. M. Cees, V. Vander. "Factors influencing student receptivity to formative feedback emerging from different assessment cultures". Perspective on Medical Education.5 276-284. 2016

[14] Z. A. Chapmaqchee. "Teachers attitude into different approaches to providing feedback to students in higher education. Journal of Education and Practice". 6(2) ISSN 222-288X.WWW.iiste.org. 2015.

[15] L. I. Eleje, N. P. M. Esomonu, R. O. Okoye, N. N. Agu, C. O. Okoi O A. Ugorji, \& C. C. Abanobi, "Students' Academic Achievement in Secondary-School Quantitative Economics: Effect of Feedback with Remediation". Education Quarterly Reviews, 3(4) pp. 479-488. DOI: 10.31014/aior.1993.03.04.155. 2020.

[16] "Chief Examiner's Report Economics" W.A.E.C. https://waeconline.org.ng.econsmain 2015.

[17] E. Mulliner, \& M. Tucker. "Feedback on feedback: Perceptions of students and academics". Assessment \& evaluation in higher education. DOI: 10.1080/02602938. 2015

[18] A. B. Rose \& J. O. Sika, Determining influence of teacher workload on academic performance of secondary schools, Suba, Sub-County Kenya. Advances in Social Sciences Research Journal, 6(3), pp. 287-295. 2019.

[19] D. O. Chirimi. "The impact of teacher workload allocation on teaching and learning effectiveness of science subjects in secondary schools. The case of Hanang District, Tanzania”. Dissertation submitted in partial fulfillment of requirement and award of masters degree in education at Mzumbe university. 2016.

[20] E. W. Kiamba, F., Mutua, \& D. Mulwa. "Influence of teacher subject matter knowledge on student academic achievement of Kiswahili language in public secondary schools in Kathonzweni Sub-County, Kenya". Scholarly Research Journal for Humanity Science and English Language. 6(29), www.srjis.com. 2018.

[21] J. E. E. Ntibi, H. A. Neji, C. Agube, "Students' perception of teacher knowledge of subject matter /lesson presentation and academic performance in physics in Calabar Municipality, Cross River state, Nigeria”. European Journal of Social Science. 56(2), pp.247-254 https://www.europeanjournalofsocialsciences.com/ 2020

[22] B. Martineau \& S. Mamede, "The influence of peer feedback on the acquisition of physical education skills". Health Professions Education, 2(2), pp.106-113. 2016.

[23] M. D. Svinicki, "Encouraging your students to give feedback. Centre for Teaching Effectiveness", USA. https//cft.vandabilt.edus.student-e. 2001.

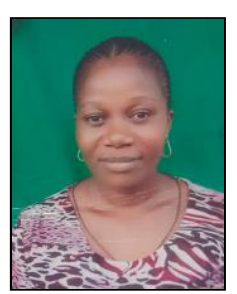

Felicitas Ogonna Ejinkonye

She was born in Ezinifite, Aguata L.G.A, Anambara State, on $11^{\text {th }}$ May 1979. She has B.ed in Educational Administration and Supervision/Economics. M.ed in Educational Evaluation, all in Nnamdi Azikiwe University Awka, Anambra State, Nigeria. 